\title{
INTERNATIONAL INTERGOVERNMENTAL ORGANIZATIONS OF SPECIAL COMPETENCE AND THEIR INFLUENCE ON THE FORMATION OF THE LEGAL SPHERE OF FOREIGN ECONOMIC ACTIVITY IN UKRAINE
}

The purpose of the study is to consider the process of development of society in the context of the dominant production relations, in the state of the economy and in its political orientation. It is noted that the political structure of society has always been subject to changes, not only in terms of changing ideas, but also in the policy regarding entrepreneurship and its position in the development of the national economy.

Research methods. In the process of studying the topic, such methods were used as the analysis of the theoretical foundations of the development of entrepreneurship as a socio-economic institution, the analysis of a special set of norms and rules that ensure the coordinated behavior of business entities.

The novelty of the study is that for the first time in a national economic study, a variety of concepts and approaches on the problems of the development of the institution of entrepreneurship were clearly classified. However, the growth of political entrepreneurship and international cooperation between entrepreneurs has caused a dramatic change in its essence, so a political analysis of the problem is key to understanding the role of the main subsystem of the modern free market economy.

Conclusions. Summing up, the author comes to the conclusion that, from the point of view, the thesis about two models of entrepreneurial behavior can help resolve the contradiction in the nature of innovation in entrepreneurship (classical and innovative). It is noted that the distinctive feature of the first model (otherwise it can also be called resource-oriented) is that the entrepreneur links tasks with available resources and prefers means of achieving goals that ensure the most efficient use of resources. The second model is focused on opportunities rather than resources, which means that the entrepreneur prefers innovative production methods using his own resources and external resources. In a word, modern entrepreneurship is a multidimensional and holistic socio-economic phenomenon of a market economy, in which multilevel (reflecting many theoretical concepts) and generalizing (reflecting many features) approaches are extremely important. It is advisable to define its economic essence.

Key words: foreign economic activity, subjects of foreign economic activity, environment of foreign economic activity, international intergovernmental organizations of special competence, international legislation, national legislation.

JEL Classification: K23, K29, K33.

\section{Andrii MINCHENKO,}

Head of the Department of Civil, Commercial and Environmental Law University of Customs and Finance, Candidate of Legal Sciences, Associate Professor minchenko.andriy@gmail.com orcid.org/0000-0002-8547-9676

\section{Anatolii MAZUR,}

Associate Professor at the Department of Administrative and Customs Law University of Customs and Finance, Candidate of Legal Sciences, Associate Professor anvas.mazur@gmail.com orcid.org/0000-0003-1073-4799

\section{Introduction}

The acquisition by a state of membership in international organizations is always a challenge to the readiness of society, the business environment, the legal framework for the inevitable changes and the influence they experience directly or indirectly in this regard. At the same time, these processes have a reverse effect on the formation of the image of the state in the international arena, strengthening its perception as a reliable partner in trade or other spheres.

Membership in international intergovernmental organizations of special competence is an important asset of a well-thought-out foreign policy of the state, which aims to create a favorable environment for the development of trade and other foreign economic relations. Ukraine is a permanent member of many international intergovernmental organizations of this type, which, of course, strengthens its foreign economic position. At the same time, the issue of the importance of state membership in such organizations for the formation of the 
environment for foreign economic activity of the relevant entities deserves special attention, because it is important today to determine the usefulness of such participation for the development of spheres of influence of each foreign economic sphere agreements. In the conditions of aggravation of economic competition the question of efficiency of participation in the specialized international intergovernmental organizations for development of these or those spheres of economy is actualized as foreign economic activity is, on the one hand, an integral part of economic activity of the enterprise, and on the other a factor of economic growth of national economy (Gordopolov, 2016).

\section{Literature review}

Well-known Ukrainian lawyers and economists have studied the problems of international intergovernmental organizations at various times. Among the studies devoted to these components, it is worth noting such authors as M. Buhrii, O. Vasylenko, O. Golovko-Gavrisheva, P. Grinko, A. Ignatiuk, S. Kasyanova, V. Kozub, L. Mykolska, L. Nosach, L. Pismachenko, E. Ryasnykh, I. Us, T. Tsygankova and other scientists. At the same time, in this article we would like to pay more attention to the study of the influence of international intergovernmental organizations of special competence on the formation of the legal environment for foreign economic activity in Ukraine.

\section{The purpose of the article}

Based on the analysis of Ukraine's membership in international intergovernmental organizations of special competence, to establish the prospects of its development for the subjects of foreign economic activity.

\section{Presenting main material}

The environment of foreign trade is formed under the influence of a number of factors. If we consider the FEA of Ukraine as a state, the effectiveness of such activities should be assessed by indicators of foreign economic relations (exports and imports, re-exports and re-imports, foreign trade debt, foreign investment, etc.), intensity (foreign trade per capita, the country's integration into the world economic systems) and the dynamics of foreign economic relations (growth and growth rates), the structure of foreign economic relations (commodity, geographical, institutional), the effectiveness of foreign economic activity (balance of payments and trade, balance of services and nonprofit payments, capital movements, official foreign exchange reserves, foreign debt) (Grebelnik, 2019: 35).

Let us consider the main aspects of Ukraine's membership in international intergovernmental organizations of special competence and the impact it has on the legal environment of national subjects of foreign economic activity.

The World Trade Organization (WTO) is an international organization whose goal is to develop a system of legal norms for international trade and control their observance. The WTO succeeded the General Agreement on Tariffs and Trade (GATT) concluded after the Second World War. Their activities contributed to the creation of a stable trading system and the establishment of global trade rules.

The WTO trading system is based on several basic principles. The key one is the principle of nondiscrimination. WTO members are obliged to give each other equally favorable conditions: no country should make exceptions for another or apply a discriminatory approach to it.

Among others, the principle of transparency - clear information about policies, procedures and rules, predictability - commitments to reduce trade barriers and expand access to their own markets are binding (Mykolska, 2018).

The Law of Ukraine "On Foreign Economic Activity" (Verkhovna Rada of Ukraine, 1991) found its place in the provisions that were developed in connection with Ukraine's membership in this organization. So, art. 7 provides for the introduction of appropriate legal regimes for goods imported from WTO member states:

- national regime, which means that in respect of imported goods originating in WTO member countries, the regime is no less favorable than for similar goods of Ukrainian origin in terms of taxes, fees established by laws and other regulations, rules and requirements for domestic sales, proposals to sale, purchase, transportation, distribution or use of goods, as well as internal quantitative regulation rules that set requirements for the mixing, processing or use of goods in certain quantities or proportions;

- the most-favored-nation treatment, which concerns customs duties, rules of collection, rules and formalities in connection with imports and means that any advantage, facilitation, privilege or immunity granted in respect of any goods of any State must be to be immediately and unconditionally provided with similar goods originating in the territory of WTO member states or states with which bilateral or regional most-favored-nation agreements have been concluded. 
These preparatory steps laid the foundation for the future successful conclusion of the Association Agreement between Ukraine and the EU, one of the main directions of which is the desire of the parties to achieve economic integration, inter alia, by creating a deep and comprehensive free trade area.

Experts focus on several key tools that Ukraine uses today in the WTO to promote and defend the interests of Ukrainian business: a) participation in multilateral trade negotiations - allows Ukraine to defend trade and economic interests and influence the formation of new rules in world trade; b) active use of WTO platforms to defend the interests of Ukrainian business - advocates, for example, a clear position of Ukraine on the consequences for international trade due to the annexation of Crimea and the Russian Federation's failure to comply with its international obligations, the need for immediate compliance as a member of the WTO and the elimination of unjustified restrictions, prohibitions and discriminatory measures on Ukrainian goods.

Ukraine has repeatedly used the mechanism of submitting specific trade concerns to the meetings of these bodies, which made it possible to draw the attention of WTO members to possible violations of obligations under the relevant agreements and demand the abolition of measures that do not comply with WTO agreements.

Ukraine actively participates in the work of WTO committees on safeguards, subsidies and countervailing measures, as well as anti-dumping practices (Mykolska, 2018).

Ukraine's participation in negotiations on the accession of new members to the WTO helps the state to defend the interests of Ukrainian producers through proposals of relevant associations of producers to remove barriers to market access and increase export potential.

In May 2016, Ukraine acceded to the Government Procurement Agreement (GPA), which enabled Ukrainian companies to participate in the public procurement of 46 countries participating in this agreement. Ukrainian entrepreneurs were given the opportunity to have access to government tenders abroad (Mykolska, 2018).

Ukraine has been given the opportunity to use a dispute settlement mechanism to help defend the interests of Ukrainian producers. During the 10 years of WTO membership, Ukraine defended its rights in seven cases - as a plaintiff, in four - as a defendant and was a third party in 19 cases (Mykolska, 2018). Compared to other countries, Ukraine actively uses the opportunity to protect its interests at the Geneva site, and legal practice under WTO law has grounds for further development (Omelchenko, 2017) despite the influence of political factors.

The WTO dispute settlement system is a central element in ensuring the security and predictability of the multilateral trading system. It serves to protect the rights and obligations of WTO members under the agreements covered, as well as to clarify the existing provisions of these agreements in accordance with the usual rules of interpretation of public international law. According to M. Buhrii and I. Us, one of the advantages of the system is to provide an opportunity for any WTO member to use an independent dispute settlement procedure to exercise their rights under the relevant WTO trade agreements (Buhrii, Us, 2011).

The procedure for protecting the rights and interests of Ukraine in the trade and economic sphere within the WTO is also separately defined at the national level in the approved Procedure for protecting the rights and interests of Ukraine in the trade and economic sphere within the World Trade Organization (Cabinet of Ministers of Ukraine, 2016), which regulates the relations arising during consultations and disputes between WTO members.

It should be noted that Ukraine's participation in the WTO is important not only from an economic point of view, but also politically, as it served as a key precondition for signing the Association Agreement with the EU, the European Atomic Energy Community and their Member States and, consequently, with 1 January 2016, the provisions on the establishment of a deep and comprehensive free trade area (FTA) enter into force for our country. They provide for significant liberalization of trade (elimination of tariffs or quotas) between the parties, harmonization of legislation and regulatory framework.

Therefore, it can be argued that Ukraine's accession to the WTO has contributed to the intensification of trade relations with member countries, strengthened the position of national companies to foreign partners, contributes to the adaptation and harmonization of legislation with European.

International credit and financial organizations: the International Monetary Fund (IMF), the International Bank for Reconstruction and Development (IBRD), the International Finance Corporation (IFC), the International Development Association (IDA) and the Multilateral Investment Guarantee Agency (MIGA). Ukraine is a member of all the above structures of the World Bank, which it joined in 
1992 (Verkhovna Rada of Ukraine, 1992). Currently, 16 projects totaling \$2,895 million and $€ 15$ million are being implemented in Ukraine at the expense of the World Bank (World Bank, 2020).

Additional legal opportunities for foreign investors were opened by arbitration with a contractual form of protection of rights (Makarenko, 2019), the International Center for Settlement of Investment Disputes (ICVIS), which, like the above organizations, belongs to the World Bank group an autonomous international institution established in accordance with the Convention on the Procedure for Resolving Investment Disputes between States and Foreign Persons signed in 1965 (United Nations, 1965). Currently, two investment disputes are being considered, in which Ukraine, in particular, is represented by the Ministry of Justice: with the participation of Emergofin B.V. and Velbay Holdings Ltd. (ARB / 16/35) and Gilward Investments B.V. (ARB / 15/33), thirteen disputes were decided (International Center for Settlement of Investment Disputes (World Bank Group)). As of now, more than eight hundred cases have been registered at the center. ICSID (International Center for Settlement of Investment Disputes) is an important means of resolving investment disputes, but it is not effective enough. After all, it should be combined with other protection mechanisms, including investment risk insurance and work to prevent such disputes (Kostyliev, 2013: 215). Disputes over jurisdiction, equality of the parties to an international investment dispute (Lazarenko, 2016: 111), rather lengthy consideration of ICSID disputes, non-compliance with its decisions, etc. does not fully meet the needs of FEA subjects. In part, the initiative to introduce "investment nannies" could be seen as a response to such a challenge.

The European Bank for Reconstruction and Development (EBRD), the European Investment Bank (EIB), the European Development Fund (EDF), the European Monetary Fund (EMF), the European Central Bank (ECB), and the European Monetary Fund play a regulatory role in the system of monetary integration in Western Europe. (EWF). Thus, the main policy of the EBRD is aimed at the rise and restructuring of Central and Eastern Europe. The EBRD's activities in this area include the provision of loans for the development of production; capital investment; guaranteed placement of securities; granting loans for reconstruction and infrastructure development. Priority areas for lending are the financial sector, energy, telecommunications, transport and agribusiness. The EBRD implements major environmental protection programs in the Baltic Sea region, the Danube Delta, and the Black Sea aquatic environment (Zin, Duka, 2009).

The state's use of financial mechanisms offered by international credit and financial organizations is extremely important not only for the state itself, maintaining its balance of payments, but also for foreign economic entities, as their activities are supported by these mechanisms. As noted by E. Ryasnykh, an effective financial mechanism of foreign economic activity allows companies to more rationally use their economic potential, gain access to new technologies, to conquer new markets for their products (Ryasnykh, 2013). Therefore, the relationship "international credit and financial organizations - the state - the subjects of foreign economic activity" is an important and necessary chain in the success of enterprises in foreign markets, which due to the implemented methods of financing foreign economic activity (lending, leasing, franchising, factoring, forfeiting) support.

During its cooperation with international credit and financial organizations, Ukraine received significant financial support from them, in return for which it had to comply with the relevant requirements, including those related to changes in national legislation. Thus, in particular, the IMF, cooperating with Ukraine on various programs, put forward demands: limit the practice of simplified taxation, lift the moratorium on the sale of agricultural land, raise utility tariffs, raise gas and heating tariffs to market levels, divide tariffs into gas and its delivery, raise the retirement age, implement pension reform, legalize amber mining and gambling, the division of the SFS into two legal entities: tax and customs services, change the rules of the NBU, which will reduce regulatory capital on loans, etc. (Slovo i dilo, 2020). Structural reforms, such as the reorganization of the tax and customs services, also shape the legal environment for conducting foreign economic activity, as do the financial and economic factors outlined here. The current Memorandum with the IMF (President of Ukraine, Prime Minister of Ukraine et al., 2020) clause 8b provides for the transformation of the State Tax Service and the State Customs Service into two single legal entities and their full pilot operation as such from January 1, 2021.

The World Bank wants to guarantee its investments by influencing the formation of domestic law and government. In turn, the subjects of foreign economic activity receive a more comfortable legal environment for carrying out their activities due to the introduced changes. 
The United Nations Conference on Trade and Development (UNCTAD) is part of the United Nations Secretariat for Trade, Investment and Development. The organization's goals are: "to maximize the opportunities of developing countries in the field of trade, investment and development and to assist them in their efforts to integrate into the world economy on a fair basis" (About UNCTAD).

Ukraine cooperates with UNCTAD units to implement joint projects in the field of small and medium business development, implementation of international financial reporting standards, creating favorable conditions for attracting foreign investment, implementation of competition policy, etc. (UN Conference on Trade and Development).

The United Nations Commission on International Trade Law (UNCITRAL) is the main legal body of the United Nations in the field of international trade rights. The main purpose of UNCITRAL is to unify and harmonize certain aspects of private international law through appropriate legal instruments, which are used as conventions, model laws, model provisions, legal principles, recommendations. The use of these tools is designed to remove barriers and improve international trade.

In 2018, Ukraine was elected a member of this commission for 6 years. During the membership period in 2010-2014, our country made a significant contribution to the development of the UNCITRAL Model Law on Public Procurement and relevant guidelines. Membership is important in terms of the ongoing process of adapting Ukrainian legislation in the field of international trade to world best practices, as well as promoting Ukraine's interests in the context of entering global markets (Ukrinform, 2018).

World Customs Organization (WCO). The main tasks of the organization are: development of international instruments for regulating customs, development and adoption of conventions on classification of goods, customs value, rules of origin, customs duties, security of supply chain, simplification of international trade, combating customs offenses and illegal movement counterfeit products (protection of intellectual property rights), as well as the fight against corruption, support for reforms and modernization of customs services.

To achieve its goals, WMO also develops appropriate customs instruments, such as the Kyoto Convention (International Convention on the Simplification and Harmonization of Customs Procedures), the Istanbul Convention (Temporary Admission Convention), the System of Framework Standards for Security and Promotion of Global Trade (SAFE), Convention on a Harmonized Commodity Description and Coding System. Ukraine is a full member of this organization (1992) and a party to most conventions. The Kyoto Convention not only influenced the formation of a new domestic customs ideology, it became a source of specific legal requirements for the current Customs Code of Ukraine.

WMO shall establish, maintain and implement international instruments for the harmonization and uniform application of simplified and efficient customs systems and procedures governing the movement of goods, persons and vehicles across customs borders. This function is extremely important for the development of foreign economic activity.

World Intellectual Property Organization (WIPO). The purpose of this international organization is to promote the protection of intellectual property worldwide by ensuring cooperation between states and compliance with the provisions of multilateral treaties governing the legal and administrative aspects of intellectual property.

Ukraine is a party to many international treaties in the field of intellectual property, the administrative functions of which are performed by WIPO. Ukraine's participation in some WIPO treaties and agreements (for example, the Patent Cooperation Treaty, the Madrid Agreement and its Protocol) makes it possible to ensure legal protection of relevant intellectual property results in foreign countries by submitting one application instead of this procedure for each country separately. In order to introduce in Ukraine the institution of arbitration and mediation in resolving disputes in the field of intellectual property with the involvement of WIPO in 2018, a bilateral Memorandum of Understanding and Alternative Dispute Resolution in the field of intellectual property was signed (Permanent Mission of Ukraine to the UN Office and other International Organizations in Geneva, 2012b).

\section{Conclusions and prospects}

Ukraine belongs to the so-called developing countries, so it is extremely important to use permanent membership in international intergovernmental organizations in order to increase the effectiveness of foreign economic policy as part of the economic policy of the state. The success of foreign economic activity of business entities has a strong dependence on the legal environment created as a result of such membership, as well as on the foreign policy of the state, which are interconnected. The study provided an opportunity to focus on some key aspects that influence the formation of a favourable, in particular the legal environment 
for foreign economic activity and demonstrate the exceptional effectiveness of foreign economic instruments in defending trade and economic interests of Ukrainian producers of goods and services.

\section{References:}

1. Gordopolov V. (2016). Suchasnyi stan zovnishnoekonomichnoi diialnosti rezydentiv Ukrainy [The current state of foreign economic activity of residents of Ukraine]. Efektyvna ekonomika, no. 11. Retrieved from: http://www.economy.nayka.com.ua/?op=1\&z=5264 (date of application: 29.07.2020) [in Ukrainian].

2. Hrebelnyk O. (2019). Osnovy zovnishnoekonomichnoi diialnosti: pidruchnyk [Basics of foreign economic activity: textbook]. Irpin: University of the State Fiscal Service of Ukraine, 410 p. Retrieved from: http://ir.nusta.edu.ua/jspui/bitstream/doc/4007/1/2830_IR.pdf (date of application: 21.07.2020) [in Ukrainian].

3. Mykolska N. (2018) Pershi 10 rokiv u SOT: yak Ukraina vykorystovuie instrumenty orhanizatsii [The first 10 years in the WTO: how Ukraine uses the tools of the organization]. Retrieved from: https:// www.eurointegration.com.ua/articles/2018/05/16/7081783/ (date of application: 21.07.2020) [in Ukrainian].

4. Verkhovna Rada of Ukraine (1991). Pro zovnishnoekonomichnu diialnist: Zakon Ukrainy vid 16 kvitnia 1991 r. № 959-XII [On foreign economic activity: Law of Ukraine of April 16, 1991 № 959-XII]. Vidomosti Verkhovnoi Rady URSR, No. 29, art. 377 [in Ukrainian].

5. Omelchenko, A. (2017). Spornyy interes [Controversial interest]. Yuridicheskaya praktika, no. 11(1003). Retrieved from: https://pravo.ua/articles/spornyj-interes/ (date of application: 24.07.2020) [in Russian].

6. Buhrii M., Us I. (2011). Uchast Ukrainy v SOT: heoekonomichnyi pohliad na zdobutky ta perspektyvy [Ukraine's participation in the WTO: a geoeconomic view of achievements and prospects]. Stratehichni priorytety, No 2. Pp. 91-97 [in Ukrainian].

7. Cabinet of Ministers of Ukraine (2016). Pro zatverdzhennia Poriadku zabezpechennia zakhystu prav ta interesiv Ukrainy v torhovelno-ekonomichnii sferi v ramkakh Svitovoi orhanizatsii torhivli: Postanova Kabinetu Ministriv Ukrainy vid 1 chervnia 2016 r. № 346 [On approval of the Procedure for ensuring the protection of the rights and interests of Ukraine in the trade and economic sphere within the framework of the World Trade Organization: Resolution of the Cabinet of Ministers of Ukraine of June 1, 2016 № 346]. Retrieved from: https://zakon.rada.gov.ua/laws/show/346-2016-п\#Text (date of application: 21.07.2020) [in Ukrainian].

8. Verkhovna Rada of Ukraine (1992). Pro vstup Ukrainy do Mizhnarodnoho valiutnoho fondu, Mizhnarodnoho banku rekonstruktsii ta rozvytku, Mizhnarodnoi finansovoi korporatsii, Mizhnarodnoi asotsiatsii rozvytku ta Bahatostoronnoho ahentstva po harantiiakh investytsii: Zakon Ukrainy vid 3 chervnia 1992 r. № 2402-XII [On Ukraine’s Accession to the International Monetary Fund, the International Bank for Reconstruction and Development, the International Finance Corporation, the International Development Association and the Multilateral Investment Guarantee Agency: Law of Ukraine of June 3, 1992 № 2402-XII]. Vidomosti Verkhovnoi Rady Ukrainy, no. 33, art. 474 [in Ukrainian].

9. Svitovyi bank [The World Bank]. Retrieved from: https://bit.ly/2Hj2mt0 (date of application: 23.07.2020) [in Ukrainian].

10. Makarenko, Ye. (2019). Mizhnarodnyi investytsiinyi arbitrazh: yak tse pratsiuie? [International investment arbitration: how it works?]. Yurydychna hazeta online, no 38-39(692-693). Retrieved from: https:// yur-gazeta.com/publications/practice/mizhnarodniy-arbitrazh-ta-adr/mizhnarodniy-investiciyniy-arbitrazhyak-ce-pracyue.html (date of application: 24.07.2020) [in Ukrainian].

11. Hrabynska, I.,Hrabynskyi, M. (2012). Ekonomichni ta pravovi pytannia uchasti Ukrainy u mizhnarodnykh ekonomichnykh orhanizatsiiakh (na prykladi hrupy Svitovoho banku) [Economic and legal issues of Ukraine's participation in international economic organizations (on the example of the World Bank group)]. Visnyk Lvivskoho universytetu. Seriia ekonomichna, iss. 47, Pp. 449-455. Retrieved from: https://intrel.lnu.edu.ua/ wp-content/uploads/2017/09/6864-13196-1-PB.pdf (date of application: 30.07.2020) [in Ukrainian].

12. United Nations (1965). Konventsiia pro poriadok vyrishennia investytsiinykh sporiv mizh derzhavamy ta inozemnymy osobamy: mizhnarodnyi dokument vid 18 travnia 1965 r. (ratyfikovanyi zakonom Ukrainy vid 16 bereznia 2000 r. № 1547-III [Convention on the Settlement of Investment Disputes between States and Foreign Persons: International Document of May 18, 1965 (ratified by the Law of Ukraine of March 16, 2000 № 1547-III]. Retrieved from: https://zakon.rada.gov.ua/laws/show/995_060\#Text (date of application: 30.07.2020) [in Ukrainian].

13. International Centre for Settlement of Investment Disputes (World Bank Group). Cases Database. Retrieved from: https://icsid.worldbank.org/cases/case-database (date of application: 30.07.2020) [in English].

14. Kostyliev, O. (2013). Bahatostoronnia systema vyrishennia investytsiinykh sporiv yak instytutsiinopravovyi mekhanizm zakhystu inozemnykh investytsii [Multilateral system for resolving investment disputes as an institutional and legal mechanism for protecting foreign investment]. Visnyk Mariupolskoho derzhavnoho universytetu. Seriia "Pravo", iss. 5, pp. 211-215. Retrieved from: http://nbuv.gov.ua/UJRN/ Vmdu_pr_2013_5_40 (date of application: 29.07.2020) [in Ukrainian]. 
15. Lazarenko, M. (2016) Problemni pytannia vyznannia ta vykonannia rishen Mizhnarodnoho tsentru z vrehuliuvannia investytsiinykh sporiv [Problematic issues of recognition and enforcement of decisions of the International Center for Settlement of Investment Disputes]. Naukovyi visnyk Mizhnarodnoho humanitarnoho universytetu. Seriia "Yurysprudentsiia", No. 21, Pp. 110-111. Retrieved from: http://www.vestnik-pravo.mgu. od.ua/archive/juspradenc21/31.pdf (date of application: 29.07.2020) [in Ukrainian].

16. Zin, E., Duka, N. (2009). Osnovy zovnishnoekonomichnoi diialnosti: pidruchnyk [Basics of foreign economic activity: textbook]. Kyiv: Kondor, 432 p. [in Ukrainian].

17. Riasnykh, Ye. (2013). Finansovyi mekhanizm zovnishnoekonomichnoi diialnosti pidpryiemstv [The financial mechanism of the economic activity of the enterprises]. Retrieved from: https://bit.ly/3o4qMrk (date of application: 23.07.2020) [in Ukrainian].

18. Slovo i dilo (2020). Yaki vymohy vysuvav MVF do Ukrainy za ostanni 26 rokiv [What are the requirements of the IMF for Ukraine over the past 26 years]. Retrieved from: https://www.slovoidilo. ua/2020/04/23/infografika/finansy/yaki-vymohy-vysuvav-mvf-ukrayiny-ostanni-26-rokiv (date of application: 23.07.2020) [in Ukrainian].

19. President of Ukraine, Prime Minister of Ukraine et al. (2020). Ukraina do MVF: Lyst pro namiry vid 2 chervnia 2020 r. [Ukraine to the IMF: Letter of Intent from June 2, 2020]. Retrieved from: https://bit. ly/348Et0k (date of application: 21.07.2020) [in Ukrainian].

20. United Nations Conference on Trade and Development. About UNCTAD. Retrieved from: https:/unctad.org/en/Pages/aboutus.aspx (date of application: 24.07.2020) [in English].

21. Permanent Mission of Ukraine to the UN Office and other International Organizations in Geneva (2012a). Konferentsiia OON z torhivli ta rozvytku (YuNKTAD) [United Nations Conference on Trade and Development (UNCTAD)]. Retrieved from: https://geneva.mfa.gov.ua/posolstvo/2608-unctd (date of application: 24.07.2020) [in Ukrainian].

22. Ukrinform (2018). Ukraina uviishla do skladu komisii OON z mizhnarodnoi torhivli [Ukraine is a member of the UN Commission on International Trade]. Retrieved from: https://www.ukrinform.ua/rubriceconomy/2603728-ukraina-uvijsla-do-skladu-komisii-oon-z-miznarodnoi-torgivli.html (date of application: 24.07.2020) [in Ukrainian].

23. Permanent Mission of Ukraine to the UN Office and other International Organizations in Geneva (2012b). Vsesvitnia orhanizatsiia intelektualnoi vlasnosti (VOIV) [World Intellectual Property Organization (WIPO)]. Retrieved from: https://geneva.mfa.gov.ua/posolstvo/2610-wipo (date of application: 24.07.2020) [in Ukrainian].

\title{
МІЖНАРОДНІ МІЖУРЯДОВІ ОРГАНІЗАЦІЇ СПЕЦАЛЬНОЇ КОМПЕТЕНЦІЇ ТА ЇХ ВПЛИВ НА ФОРМУВАННЯ ПРАВОВОГО СЕРЕДОВИЩА ПРОВАДЖЕННЯ ЗОВНІШНЬОЕКОНОМІЧНОЇ ДІЯЛЬНОСТІ В УКРАЇНІ
}

\author{
Андрій МІНЧЕНКО, \\ завідувач кафедри цивільного, господарського та екологічного права \\ Університету митної справи та фінансів, \\ кандидат юридичних наук, дочент \\ minchenko.andriy@gmail.com \\ orcid.org/0000-0002-8547-9676
}

Анатолій МАЗУР, доиент кафедри адміністративного та митного права

Університету митної справи та фінансів, кандидат юридичних наук, доцент anvas.mazur@gmail.com orcid.org/0000-0003-1073-4799

\begin{abstract}
Статтю присвячено дослідженню проблем діяльності міжнародних міжурядових організацій спеціальної компетенції та впливу, який вони справляють на формування правового середовища провадження зовнішньоекономічної діяльності в Україні.

Метою статті $\epsilon$ встановлення перспектив розвитку членства України в міжнародних міжурядових організаиіях спеиіальної компетениії для наиіональних суб 'єктів зовнішньоекономічної діяльності.

Методологічну основу дослідження становлять сучасні загальні та спещіальні методи наукового пізнання. Застосування цих методів зумовлюється системним підходом. Зокрема, використані діалектичний
\end{abstract}


метод - для встановлення основних закономірностей, щзо властиві відносинам зовнішньоекономічної діяльності; логіко-семантичний метод - для з'ясування основних термінів і понять, щзо використовуються в дослідженні, а також ознак, притаманних відповідним міжнародним організаціям (Світовій організації торгівлі, міжнародним кредитно-фінансовим організаціям, Конференції ООН з торгівлі й розвитку, Комісії ООН з права міжнародної торгівлі, Всесвітній організачії інтелектуальної власності, Всесвітній митній організації); метод системного аналізу - для дослідження сучасного стану розгляду изього питання в Україні, а також задля співвіднесення ролі окремих міжурядових організацій спеиіальної компетенції у правовому середовищі України; формально-логічний метод - для з ясування змісту категоріального апарату дослідження; порівняльно-правовий метод - для порівняння міжнародного законодавства з національним законодавством України; метод аналізу та синтезу - у визначенні змісту ознак, притаманних міжнародним міжурядовим організачіям спеціальної компетениіі.

Дослідженням встановлено, що використання державою фінансових механізмів, які пропонуються міжнародними організаціями, має надзвичайну вагомість не лише для самої держави, а й для суб'єктів зовнішньоекономічної діяльності, адже їх діяльність підтримується за допомогою ичих механізмів.

Проведене дослідження дало змогу резюмувати: з огляду на те, щзо Україна належить до країн, щзо розвиваються, украй важливим є постійне членство в міжнародних міжурядових організаціях із метою підвищення ефективності зовнішньоекономічної політики як складника економічної політики держави. Крім того, можна підкреслити, щь успішність ведення суб 'єктами господарювання зовнішньоекономічної діяльності має стійку залежність від створюваного внаслідок такого членства правового середовища та від зовнішньополітичного курсу держави, які перебувають у взаємозв язку.

Проведене дослідження дало можливість акцентувати увагу на окремих ключових аспектах, щзо справляють вплив на формування сприятливого середовища, зокрема правового, для провадження зовнішньоекономічної діяльності, а також продемонструвати виключну ефективність використання зовнішньоекономічних інструментів впливу в разі відстоювання торговельно-економічних інтересів українських виробників товарів і послуг.

Ключові слова: зовнішньоекономічна діяльність, суб'єкти зовнішньоекономічної діяльності, середовище провадження зовнішньоекономічної діяльності, міжнародні міжурядові організації спеціальної компетенції, міжнародне законодавство, національне законодавство. 